\title{
The Risk Structural of European Sovereign Credit Default Swap Before and After in European Periphery Countries
}

\author{
Iş11 Tellalbaş1 ${ }^{1}$ \\ ${ }^{1}$ Department Banking and Finance, Abant Izzet Baysal University, Bolu, Turkey \\ Correspondence: Işıl Tellalbaşı, Department Banking and Finance, Abant İzzet Baysal University, Bolu, Turkey. \\ Tel: 9-374-311-2111. E-mail: isiltel@gmail.com
}

Received: October 25, 2013

Accepted: November 14, 2013

Online Published: December 23, 2013

doi:10.5539/ijef.v6n1p165

URL: http://dx.doi.org/10.5539/ijef.v6n1p165

\begin{abstract}
This study has represented the determinants of sovereign CDS spreads during current sovereign debt crisis in periphery countries namely Ireland, Italy, Portugal and Spain. The period of analysis is between 2008 and 2012 years. After the demise of Lehman Brothers, the sovereign CDS market has attached significant attention and the credit markets have been issue to an unprecedented re-pricing of credit risk. Moreover, Lehman Brothers devastated investor confidence and decrease in the availability of credit. Massive assistance of the banks was heightened public sector deficit. Thus it has led to high level sovereign debt. This means that the risk of default of sovereign became real in periphery countries. This study has been classified three phases. Firstly an analysis of credit default swaps and their use in the financial World. Secondly development of the European periphery economy on a macro level in Portugal, Ireland, Italy and Spain. Finally the statistical approach of ordinary least square is to be analysed. Main purpose of this study will identify sovereign credit default swaps associated with the current sovereign debt crisis.
\end{abstract}

Keywords: derivatives, credit default swap spreads, CDS market, default risk, sovereign debt crisis

\section{Introduction}

In previous years, lenders to countries could not insure against sovereign default and also they had to trust creditors their debt obligation in good faith. On the other hand, our generation has created insurance product to protect against default. Basically, these insurance products are called credit default swaps which have passed two decades of extraordinary growth. Policy makers, market participants and regulators gradually look at sovereign credit default swap (CDS) spreads to adjust financial system (Augustin, 2012).

Sovereign credit ratings have helped as the most utilised proxy to measure the amount of credit risk associated with an economy; however criticism is being directed towards the rating agencies that identify credit ratings. The general idea is that the credit ratings are not good indicators of the amount of credit risk linked to an entity (Mora, 2006). This idea is related to the current sovereign debt crisis and also the subprime banking crisis 4 years ago. Credit rating agencies could not forecast this crisis. The most outstanding example of this was the collapse of the American investment bank Lehman Brothers. Even though this bank had a very high credit rating, it had defaulted (Flannery, 2009). Credit ratings have heightened the demand for a different and certain proxy of sovereign credit risk.

Moreover, the credit default swap spreads might be a substitute to utilise of credit ratings as the guiding indicator for sovereign risk. The premium that has to be paid in a sovereign CDS transforms the amount of credit risk regarding the entity fundamental the contract. Basically, a CDS contract can protect an investor versus the credit risk that he or she faces. Because CDS spreads market-assessed reflectors unlike credit ratings, they can manage more certain and also quicker to altering market conditions (Flannery, 2009). The CDS has become a very well-known instrument, as well as it is the most traded derivative and the market. This study is to define that sovereign CDS spreads can potentially be used as an underlying and accurate proxy for sovereign risk.

Furthermore, this study wants to show those sovereign defaults can severely devastate the global financial stability. The sovereign credit risk that is related to a nation has a bigger effect on the financial system than market liquidity risks, emerging market risks, and macroeconomic risk. The major reason why sovereign defaults are damaging financial sector that is due to the related spill over effects. Firstly, high sovereign risks enhance the 
correlation of risk premia. An increasing risk premium of a country triggers the risk premium of nearby economies, although these economies might not experience liquidity problems. Another impact is that financial distress damages investors to behave more herd-like. The final dangerous impact is spill over effect which is damaged bank funding sources. This causes defaults or debt restructuring as long as there is no supranational intervention. Most of European nations require the help of the ECB or the International Monetary Fund. The countries, which have sovereign debt problem, have been raising debt level, thus they would be unable to serve their debts independently in the near future.

Periphery countries, such as Greece, Ireland, Italy Spain and Portugal are characterised by the high levels assets that have paid attention from the markets and the media. This study is to explain the analysis of the determinants of sovereign CDS spreads in the euro area periphery countries which include Ireland, Spain, Portugal, and Italy. As well as, this study is to identify sovereign CDS market and its interaction with the current sovereign debt crisis. Even though CDS spreads are the price of credit risk, the determinants of CDS spreads facilitate an understanding of which risk factors are associated with entering a CDS contract. A deeper understanding of the drivers of CDS spreads also let the financial markets which utilise the CDS spreads as a good indicator in order to assess the effect of alters in global and also local factors on the price of credit risk.

European countries extended important amounts of loans to banks in order to avoid huge bank bankruptcies. This development might have caused investors to assume government guarantees on the liabilities of the financial sector. For instance, Ireland's bank assets were about five times as large as its GDP between 2003 and 2006 (Dieckmann \& Plank, 2011).

This study analysis is based on the empirically observed the relationship among sovereign CDS spreads, the equity index and volatility index. As well as, this study is to show that the breakdown of financial sector is related to a larger CDS spreads. CDS spreads is based on the financial services industry which demonstrates a strong co-movement with the health of financial system.

Furthermore this study is to examine macroeconomic development and relation with CDS spreads in Portugal Italy, Spain and Ireland. For instance, the ratio of debt to GDP is related to a country's CDS spreads. Researchers have shown that not only financial sector is related to higher CDS Spreads; nevertheless financial shock is also related to higher CDS spreads.

\section{Literature Review}

Credit Default Swap was invented by JP Morgan in 1997. It has become the most important form of credit derivatives. In a credit default swap, the protection seller facilitates to compensate the protection buyer, as long as default event exists before maturity of the contract. As long as there is no default event before maturity, the protection seller pays nothing. Researchers utilise as a theoretical framework the structural model which was introduced by Merton (1974). This model uses for the analysis of the corporate risk.

Duffie (1996) studied the relationship between treasury yield and bond yield spread. Later on, Duffie (1999) investigated the relationship between recovery rates and corporate bonds. He used different indexes to determine these relationships. He also dealt with the relationship between bond yields and yield spread which base on Moody's yield indexes.

Landscoot (2004) studies that the term structure of credit default swap on Eurobond investment between 1998 and 2002. His analysis is statistically significant and there is a positive relationship between credit default and volatility, as well as changing credit spread volatility triggers financial and macroeconomic variables.

Gapen et al. (2005) developed structural model towards sovereign credit risk, thus it provided that a contingent-claims is relied on valuation of default risky government bonds. Gapen (2005) illustrates that the major point of the risk of sovereign default is the volatility of sovereign assets and a country's leverage.

Longstaff and Neis (2005) displayed using CDS spreads to analyse bond yields and find that the non-default component is time-varying and affected by bond liquidity factors. Subsequently, investigate the corporate bond yields utilising the term structure of CDS spreads and non-default component fluctuates with market liquidity and macroeconomic variables. Tang and Yan (2007) identified that the liquidity and liquidity risk affects corporate and sovereign spreads.

Alexander and Kaeck (2007) studied on a Markov switching model in order to explain the determinants of iTraxx Europe Index in two distinct regimes.

Barrios et al. (2009) investigated government bond yield spreads in the euro area during financial crisis and he found that there is a relationship between sovereign risk premium and foreign debt. 
Dellate (2010) studies the interaction between European sovereign credit default swaps and bonds. He used panel data for the crisis period between 2008 and 2010. He investigated 11 the euro area countries, namely Finland, Denmark, Netherland and France "High Yield", another countries consist of Greece, Italy, Ireland, Spain, and Portugal. As a result, high volatility in CDS prices trigger panic in Eurozone. Therefore, CDS spread is indicator of default risk.

Atrissi and Mezher (2010) examined the current sovereign debt crisis and its interaction with the CDS markets. Moreover, they studied Greek's and other European's economic and debt policies. They tried to explain the sovereign debt problems with a special focus on CDS agreements. They said that measures and variables can be used consisting of CDS spreads, indexes volumes which use regression and other quantitative techniques.

Bolton and Olivier (2011) investigated contagion effect of sovereign debt crisis in Europe by using data of 2010 stress test. He found that the problem of Government Debt is the lack of fiscal integration and monetary integration. He said that banks have played an important role in euro are sovereign spread.

Puig and Rivero (2011) studied that macroeconomic imbalances and banking system is an important issue for peripheral EMU countries, such as Greece, Ireland, Portugal, Italy and Spain during sovereign debt crisis. They used daily data of 10 year bond yield between 1990 and 2010.

Klieber defines (2012) that the protection seller of a CDS can be insurance company or big banks, they receive monthly payment from the protection buyer. As long as a default exists, the protection seller has to pay the protection buyer the agreed amount. Basically, the protection seller charges a fee for the protection. Bomfim also defines (2005) that the annualized insurance is known as the credit default swap or credit default swap premium in the CDS market.

Actually, CDS spreads are not subject for liquidity risk, but there has been expanding literature that deals with the importance of liquidity in the CDS market.

Andrew and Longstaff (2011) defined the sovereign CDS spreads in default risk and risk premium components. Tang and Yan (2007) identified that the liquidity and liquidity risk affects corporate and sovereign spreads.

Guidance on the CDS contracts is given via the international Swaps and Derivatives Association (ISDA). ISDA has played a vital role in the development of the CDS market by supporting a standardized contract in 1998 which was updated in 2003. They behave as non-voting staff for the Credit Determination Committee.

\section{Credit Default Swap}

Credit derivatives can be either a corporate entities or a sovereign nation for instance, one is able to buy and sell protection against default by $\mathrm{ABC}$ corporate. One also may buy and sell protection against default by Countries, such as Greece, Ireland, and Portugal. In fact, the CDS markets resemble regardless of whether the reference entity is a sovereign or a corporate. For instance, contracts sold on sovereign debtor consists of moratorium and debt repudiation as credit events, however contracts that reference corporate debt do not contain events.

The credit default swap which is shown by Figure1, is a mutual financial contract in which the protection buyer has to pay a periodic fees, typically defined in basis point per annum, paid on the notional amount, in return for a contingent payment by the protection seller following a Credit events as regards a reference entity (JP Morgan, 2010).

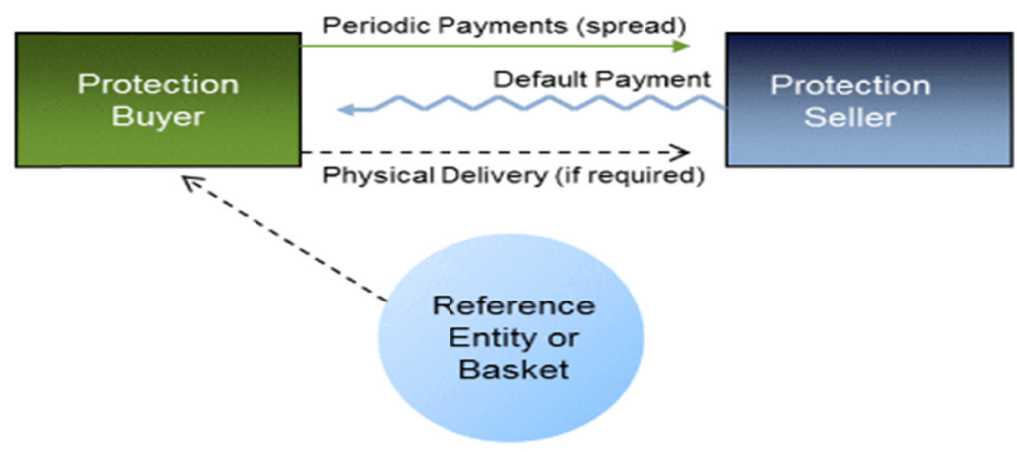

Figure 1. Credit default swap 
According to Klieber (2012), the buyer of a credit default swap allows to make a regular payment, which is similar to a monthly insurance, to insure versus a debt default by a company or government that we called reference entity. If there is a default event, the owner of the CDS has to receive lump sum payment. Basically reference entity could be a corporation, such as Mercedes, or a sovereign borrower, such as Portugal. Moreover, reference obligation is a bond or loan by the reference entity. According to Bomfim (2005) if default occurs, a CDS can be settled physically or in cash. For a physically, the protection buyer can sell (deliver) a type of defaulted asset to protection seller who gets as payment the face value of asset.

Furthermore, according to Klieber (2012) the main purposes of a CDS are hedging and transfer the risk. Basically, investors hedge versus the risk of a default. Despite the fact that credit default swaps are used as an insurance contract, some investors may use CDS for speculative purposes. A protection seller (the insurer) facilitates make a payment to the protection seller as long as a credit event happen that we usually defined as bankruptcy. Klieber defines (2012) that the risk of default is forwarded from the CDS buyer to the seller of the swap as insurance.

Credit default swaps are defined over the counter (OTC) derivatives which means that CDS are traded among two parties and not whereby an exchange or clearing house. Over the counter trading is the largest part of the derivative market. However it is unregulated regarding disclosure of information between the traders and third parties. In fact, OTC derivatives, such as CDS, have counterparty risks on the grounds that each counterparties rely on other perform.

\section{Using Credit Default Swap}

Generally, sovereign credit default swap contracts are used as trading instrument rather than pure insurance. At the most basic level, the protection seller desires to use credit default swap to receive default insurance; he or she utilises CDS as an additional source of income as well. However, investors use CDS for other aims.

Many banks and holdings use credit default swap to hedge their credit risk and country risk. Therefore, although credit instruments remain in the holder's balance sheet, the credit risk is forwarded to protection seller underneath the CDS contract. Moreover, some investors receives CDS contract, even if they don't face any exposure, it is known a naked position. During financial crisis, investors or banks, speculators have been charged with escalating the crisis using naked positions.

\subsection{Static Replication}

There is no magic formula that tells us how to determine the fair price of CDS. Investors utilise several approaches the price of credit derivatives and static replication is also another factor to determine the price of CDS. Static replication is based on credit risk model. The advantages of static replication approach is based on observe market prices. This means that one should be able to determine the fair value of the credit default swap without having to know default probabilities as regards the reference entity.

Duffie and Singleton (2003) identified that the buyer's position resembles short selling the underlying default able to bond and investing the proceeds in a par value floating rate note which means that the investor is to pay risk free rate on the short selling position, $\mathrm{Rf}+\mathrm{S}$. It depends on the credit quality of the issuer. Investor is also to receive coupons on the default floating rate note Rf. Net payment is shown below:

$$
-(R f+S)+R f=-S
$$

Nevertheless for investors, it is impossible to short sell the underlying bond in the real world. Instead, market participants prefer repurchase agreement (REPO). Furthermore, seller's position is similar to going long in the underlying bond and shorting one risk free floating rate government bond which means that the protection seller is to receive $\mathrm{Rf}+\mathrm{S}$ from long position $\mathrm{Rf}$, as well as seller will receive $\mathrm{S}$. However, it is impossible to find replicating portfolio in some cases, so modelling can be taken into consideration.

\section{Structural Approach}

In order to understand the structural approach to credit risk modelling, Black, Scholes (1973) and Merton (1974) model should be taken into consideration (Bomfim, 2005). The BSM model was relied on the corporate credit risk. Subsequently, Gapen et al. (2005) added this model to sovereign credit risk. He investigated that sovereign risk indicators are the volatility of sovereign assets and country's leverage. However According to Pan and Singleton (2008), the basic model for pricing CDS is similar to the model for used corporate CDS. The BSM model can take into account a firm with a simple capital including a zero coupon bond with face value, $\mathrm{K}$, and maturity, $\mathrm{T}$, an equity share. Therefore, the price of Bond with face value, $\mathrm{K}$, is $Z^{d}(t, T) K$. In order to demonstrate, the market value of the equity share, a new variable should be added. Later on, the market value of 
the corporate asset is:

$$
A(t)=E(t)+Z^{d}(t, T) K
$$

The BSM model is a straightforward to determine firm's value. Default is identified as the event at time T, when the corporate's debt $(\mathrm{K})$ is greater than the value of the corporate's assets:

$$
\mathrm{A}(\mathrm{T})<\mathrm{K}
$$

Hull defined (2004) that default only exists at maturity T; moreover, as long as the value of the corporate asset is below the face value of the debt, default will exist. If the firm defaults, the debt holders receice $A(t)$ but the shareholders receive nothing; if the firm does not default, the debt holder will reveice $\mathrm{K}$. If $Z^{d}(t, T) K$ is the amount that the debt holders receive at time $\mathrm{T}$, the payout for the bond holders can be demonstrated as :

$$
Z^{d}(t, T) K=e^{-R(t, T)(T-t)} K-p(t, A(t) ; T, K)
$$

When prices are the time $t:$

$$
Z^{d}(t, T) K=e^{-R(t, T)(T-t)} K-p(t, A(t) ; T, K)
$$

The shareholders get either $\mathrm{A}(\mathrm{T})-\mathrm{K}$ or nothing at time T. Shareholders' payoff can ben shown as:

$$
E(T)=\operatorname{Max}(A(T)-K), 0)
$$

Equation 4 is similar to the put option sold on the firm's assets with strike price "K". This put options seems a negative mark. This means that the bond holders have a position resemble to be short in the put option. Equation 6 can be demonstrated that the share holder's payout resembles the payoff from a call option sold on A with a strike price, K. Equation 6 can be rewritten:

$$
E(T)=A(T)-K+\operatorname{Max}(K-A(T), \quad 0)
$$

Equation 7 illustrates that the share holder's position equals a portfolio which consists of a long position in the put option, and it is bought from the debt holders (Bomfim, 2005). Equation 5 demonstrates that the higher value of the put option leads to a wider credit spread. The BSM is explained credit spread as:

$$
S(t, T)=Y(t, T)-R(t, T)
$$

Where $\mathrm{R}(\mathrm{t}, \mathrm{T})$ is the rate on a risk zero coupon bond, and $\mathrm{Y}(\mathrm{t}, \mathrm{T})$ is the yield to maturity on defaultable bonds. In order to explain credit risk spread, yield to maturity, $\mathrm{Y}(\mathrm{t}, \mathrm{T})$ is shown:

$$
Z^{d}(t, T)=e^{-Y(t, T)(T-t)}
$$

A higher value of the put option leads to a higher probability of exercise price. This means that the firm is more likelihood to default.

\section{Credit Default Swap Valuation}

According to the BSM (1976), the bondholder is short a put option on the value of the firm. Nevertheless the price of this option has not been derived yet; therefore the firm's credit is related to the capital structure of the firm. The BSM model is based on actual probabilities. Brownian model was extended the BSM model:

$$
\frac{d A(T)}{A(t)}=\mu d t+\sigma d w(t)
$$

Where $\mathrm{dw}(\mathrm{t})$ is an infinitesimal increment, and $\mu$ and $\sigma$ constant. Equation 10 shows that the firm value is log-normally distributed. The term structure of riskless interest rate is flat and constant $R(t, T)$. The firm's credit spread is calculated as:

$$
e^{-r(T-t)} K / A(t)
$$

Pricing CDs means determining the premium " $\mathrm{S}$ " that is to be paid regularly with the protection buyer. The value of premium and protection legs is paid periodically, as well as the contract has a notional amount of $\$ 1$, so the present value of the premium leg is shown:

$$
\varphi(t)=\int_{t}^{T} S Z(t, v) Q(t, v) d v
$$

Protection leg equals to a contingent claim that pays (1-x), in the case of default. $\theta(t)$ Illustrates the value of the protection leg is written:

$$
\theta(t)=(1-t) \int_{t}^{T} Z(t, v)[-d Q(t, v)]
$$

Pan (2002) defined that the annualized probability of default is written: 


$$
H(t, T)=-\log (Q(t, T)) / T-t
$$

Where $\mathrm{H}$ is approximately constant as $\mathrm{t}$ and $\mathrm{T}$ vary

$$
S=\left((1-X) \int_{t}^{T} Z(t, v) e^{-h(v-t)} h d v\right) / \int_{t}^{T} Z(t, v) e^{-h(v-t)} d v
$$

As a result, the credit default swap premium is related to recovery rate and the annualized probability of default regarding reference entity.

\subsection{Reduced-Form Approach}

The reduced-form approach takes default in order to be exogenous case that exists at unknown times. $\tau$ show the time of default that is a stochastic variable. This approach assigns probabilities to different consequents, including $\tau$. The probability can be written as:

$$
Q(t, T)=\operatorname{Probt}(\tau>T, \tau>t)
$$

As we mentioned above that structural models let for the time of default in order to be stochastic, nevertheless $\tau$ is determined endogenously by the value of the firm. But according to the reduced-form model, the stochastic characteristics of $\tau$ are identified as an exogenous variable which is not directly connected with the balance sheet of the firm (Bomfim, 2005).

\subsection{Concept of the Basis between CDS and Bonds}

Commonly, both sovereign CDS and government bonds offer investors exposure to the risk and return of sovereign debt. The basis is explained as the CDS spread minus the credit spread on a fixed rate bond of same maturity. There is a relationship between the market prices of bonds and credit default swap might offer information on the potential existence and size of arbitrage opportunities which should be very small as long as credit markets are functioning normally (European Central Bank, 2010). In order to discover a negative basis an arbitrage trader has to support the buying of underlying bond and they have to buy protection in the CDS market.

\begin{tabular}{|c|c|c|}
\hline & $\frac{C D S>\text { Bond Spread }}{\text { ('positive Basis') }}$ & $\frac{C D S<\text { Bond Soread }}{\text { ('negative Basis') }}$ \\
\hline Strategy & Sell CDS protection and bond & Buy CDS protection and bond \\
\hline Observed for & Most sovereigns & Corporates since crisis \\
\hline
\end{tabular}
In order to positive basis, a trader sells the underlying bonds in the short term and buy CDS protection for a risk-free profit and vice versa. These two cases are demonstrated below this table:

Figure 2. CDS and bond spreads

Source: (European Central Bank, 2010).

As we can be seen above this table, there is a negative relationship between CDS and Bond spread. Trading on the negative basis trade has difficulty in implementing in practice because of the funding liquidity shortage and the increased counterparty risk in the financial sector.

Credit default swap and bond spreads are the main indicators to determine the default risk during the euro area debt crisis. Fontana and Scheicher defines (2010) that CDS spreads and bond spreads are anticipated to stay close, nevertheless the relation between sovereign CDS and bond spreads has altered due to different patterns euro area countries from the Lehman Brother collapse to 2010.

\section{Emprical Analysis}

\subsection{Hypotheses and Hypostudy Testing}

A hypostudy might be concerned as a statement of the empirical correlation between a set of variables. A statistical hypostudy is about the parameters of a probability distribution, which may be of the variables or the coefficients relationship between the dependent and independent variables. Statistical hypostudy are usually studied by a null hypostudy, which is called as $H_{0}$, and an alternative hypostudy, which is called as $H_{1}$. In the null hypotheses, there are two types of error that can happen. Firstly, error 1 can exist when the null hypostudy is rejected when true. Secondly, type 2 error can occur when null hypostudy is not rejected when false. The 1 error 
is controlled by the significance levels. The significance level of test shows the probability that null hypostudy has been falsely rejected. The significance level is assigned first in most experiments, later on; type 2 is minimized by choosing more powerful statistical tests.

A regression model is a statistical model which affects one or more random variables on other variables. In general, a simple linear regression model can be shown:

$$
Y=B_{1} X_{1}+B_{2} X_{2}+. .+B_{k} X_{k}
$$

On the left side of the equation, $\mathrm{Y}$ is the dependent variable. On the right side of the equation, $\mathrm{k}, X_{1}, X_{2}$ is the independent variables. These variables always called explanatory variables, on the grounds that they explain the behaviour of the dependent variables on this model. $\mathrm{K}$ coefficients $B_{1}, B_{2}$. These variables are not random variables. The coefficients are to be estimated utilising data on dependent and independent variables. Each coefficient influences alter in its independent variables which will have upon Y.

The estimated model can be utilised to:

1) Forecast value of dependent variables, which uses scenarios on the dependent variables;

2) Test for financial theory;

3) Predict the quantities of financial asset in order to purchase or sell as forming a diversified portfolio.

Ordinary Least square is the best method to predict the model parameters when a certain assumptions hold. Moreover, the analysis of variance (ANOVA) and the OLS are straightforward for the simple model formula.

The linear model also consists of error term and alpha. A low correlation between $\mathrm{X}$ and $\mathrm{Y}$ denotes that the error term can a relatively high or low variance.

$$
Y=\alpha+\beta_{1} X_{1}+\beta_{2} X_{2}+. .+\beta_{k} X_{k}+\varepsilon
$$

Where $\alpha$ and $\beta$ demonstrate the prediction of the line intercept $\alpha$ and slope $\beta$.

Furthermore, $\mathrm{P}$ value can be used as an alternative approach in assessing the significance of regression coefficients. The $\mathrm{P}$ value illustrates the lowest level at which the null hypostudy would be accepted for a test. It is very beneficial, because the significance levels chosen for a test are generally optionally. $R^{2}$ measures the proportion of the variation in the dependent variable accounted by the explanatory variables.

The $\mathrm{F}$ value provides a hypostudy test that true slope coefficients are simultaneously zero. If $\mathrm{F}$ value test exceeds the critical $\mathrm{F}$ value. The true slope coefficients are simultaneously zero.

Furthermore, volatility is a measure of the distribution of returns for a given security of market index. Volatility can also be measured via utilising the standard deviation or variance between returns from security or market index. The Market iTraxx SovX indexes are a family of sovereign indexes which cover country around the world. The indexes have 5 years and 10 years maturities, and the currency is dollar dominated. In this study, we are using the Market SovX Western Europe is a tradable index arranged of up to 15 equally weighted sovereign constitutes from 18 European countries that we have investigated 4 countries: Ireland, Portugal, Spain, and Italy, trading on western European countries. Moreover, variance measures the volatility that is a measure of risk. Thus, this statistic can aid assess the risk an investor.

On the other hand, the problem with linear regressions is that a large number of explanatory variables might have a high degree of relationship between themselves. The problem is called as multicollinearity. Perfect multicollinearity exists when two or more independent variables are perfectly correlated. In this case the OLS estimators can't occur.

\subsection{Internal Validity}

The internal validity of an experiment is accessed via how much control has been accomplished in the study. The higher internal validity, the greater the control achieved. A high validity means that the changes in the dependent variable have been brought via the explanatory variable, not via other confusing factors. Defects in the research studies lead to a low internal validity. In our research studies, there is no problem regarding weaknesses or deficiencies in iTraxx sovereign CDS spreads or equity indices.

\subsection{External Validity}

An experiment which has a low internal validity will also have a low external validity. In this study, the problem of the external validity can be the time validity of study. The time validity of a study means that when there is a structural change between variables, the external validity will be low. However, there is no structural change in our data thus the external validity is high. Besides, there is a significant relationship between databases in certain 
research area. Due to external and internal validity are high, we use econometric models reliably.

\subsection{Data Description}

This study investigates CDS spreads on 4 countries in the euro area periphery, namely Spain, Ireland, Portugal, and Italy, as well as German CDS spreads is considered a benchmark across periphery countries. Data includes 5 years single name dollar-dominated CDS spreads. The market date includes a set of daily to observation. Specifically, the date commences from 4 March 2008 to 3 May 2008, aggregate 1072 observations, the data was obtained from Thomson Reuters and Yahoo Finance. Besides, macroeconomic data was obtained by IMF data and statistics.

\subsection{Research Methodology}

Longstaff, Pan, Pedersen, and Singleton (2010) worked on the sovereign credit risk utilizing an extensive sample of Credit Default Swap spreads for 26 developed and emerging countries. They found that sovereign credit spreads are correlated with the U.S. stock and high yield bond markets, global risk premium and capital flows. An important amount of the variation in sovereign credit return might be guess using U.S. equity, volatility and bond market risk premium. The data includes market quotations for CDS contracts in 26 developed and emerging countries. These countries are Brazil, Bulgaria, Chile, China, Colombia, Croatia, Hungary, Israel, Japan, Korea, Malaysia, Mexico, Pakistan, Panama, Peru, Philippines, Poland, Qatar, Romania, Russia, Slovak, South Africa, Thailand, Turkey, Ukraine, and Venezuela. They appointed that CDS spreads shows the market's assessment of the sovereign's credit risk. They used a principal components analysis to determine CDS spreads. A principal component analysis shows that more than 30 per cent of the variation in sovereign CDS spreads is defined by global factors that influence almost every country which they mentioned. Firstly, there is a correlation of 70 per cent with U.S. stock market return, as well as 66 per cent with alters in the VIX volatility index. Subsequently, in order to understand the determinants of sovereign credit risk, there is a great deal of explanatory variables to determine CDS spreads, for instance local economic variables, global financial market variables and global risk premium measure. Their data covered the 2000-2007 periods and investigate the correlation structure of sovereign CDS spreads. This data obtained from the Bloomberg system that collects CDS market quotation data from industry sources. In order to discover the interpretation of the first principal component, they calculate a time series for first principal component. In the absence of direct measures of the several potential risk premiums in sovereign credit spreads, they determined the approach of utilizing risk premium estimates from other global markets. One proxy measure in the risk premium, they used monthly change in prices for the S\&P100 Index. Another proxy measure for the risk premium is that changes in the spreads between implied and realized volatility for index option, such as S\&P500 volatility index.

Furthermore, Longstaff, Pan, Pedersen, and Singleton (2010) also used regression analysis. They regress the monthly changes in the CDS spreads on the explanatory variables. According to their regression analysis, the most significant variable is the U.S. high yield spread, as well as they also found that this variable is not just significant for countries with high CDS spreads but it is also significant for seven countries in the sample. Moreover, the U.S. stock market is an important variable for sovereign CDS spreads in model. It is significant for seven countries in the sample. Their regression results showed that there is a relationship between sovereign CDS spreads and Global risk premium that consists of as a explanatory variables.

As a result, Longstaff, Pan, Pedersen and Singleton (2010) found that both the U.S. equity market index and VIX index are correlated with CDS spreads.

Pan and Singleton (2008) found that VIX index is highly correlated with CDS spreads. Moreover they defined the term structure of CDS spreads. They said that the term structures of spreads show not just the rates of credit events, but also the loss rates given credit events. They analysed Mexico, Turkey, and Korea. They used a regression analysis of the correlation between risk premium and U.S. VIX option volatility index which shows as a measure of event of risk, the spread between the 10 year return on industrial corporate bonds, and 6 month U.S. Treasury bill rate which demonstrates as a measure of both U.S. macroeconomic and global financial market development as well as the volatility in the currency option corroborates their economic interpretations the changes on the risk premiums in the sovereign CDS. Pan and Singleton (2008) said that VIX index is a measure of event risk in credit markets. Moreover, they found that a strong correlation between VIX volatility and U.S. corporate credit spreads with using PCA. A domestic equity volatility index is also highly correlated with CDS spreads and VIX index is a key factor in investor's appetite for global.

They also used Monte Carlo analysis of the small sample distribution of various moment shows that many aspects of the implied distribution of CDS spreads for Mexico and Turkey. They investigated default and recovery implicit in term structure of sovereign CDS for banks, corporate and sovereign. Their sample includes 
daily trader quotes of bid and as spreads for CDS contract with maturities of $1,2,3,5$ and 10 years. The data covers the period from 2001 to 2006 , their explanatory variables are volatility index and the spread between the U.S. industrial 10 year yield and the 6 months Treasury bill yield. They show that VIX index is a measure of event risk in credit markets. Pan and Singleton (2008) found that a strong correlation between VIX volatility and U.S. corporate credit spreads with using PCA. A domestic equity volatility index is also correlated with CDS spreads.

Alexander and Kaeck (2007) studies for changes in CDS spreads are not only significant determinant by the firm's equity value but also affected by the equity volatility and risk free interest rates. They work that the higher the equity volatility, the higher the firm's value volatility, leading to an upward trend in the CDS spread. Furthermore, a low risk free rate increases default probability in the CDS market. When we look at the theoretical approach, there is a negative relationship between credit default spread and risk free interest rate. Vorst and Houweling (2005) utilize the swap rate for measuring risk of free interest rate and find stronger influences of the swap rate on the CDS market than treasury rate.

Dieckmann and Plank (2011) investigated determines the price of insurance against default of 18 economies. They used the market data base which includes mid quotes of actively traded CDS market on 18 countries which belong to the western European sovereign CDS market. These countries are Belgium, Czech Republic, Denmark, Finland, France, Germany, Greece, Hungary, Ireland, Israel, Italy, Netherlands, Poland, Portugal, Slovenia, Spain, Sweden, and the U.K. The date covers between January 2007 and April 2010. They used an augmented Dickey-Fuller test and principal component analysis to analyse sovereign CDS spreads. The first principal component explains $75 \%$ of sample variation. For domestic stock market returns, the first principal components explain $\% 65$ of sample variation. Their explanatory variables are European equity index Stock 50, V2X volatility index and a European high yield and investment grade index. The V2X volatility is significantly positively associated with the principal component. They also found that interest rate is statistically insignificant. Moreover, their empirical analysis is a cross sectional regression of CDS spreads on explanatory variables, such as the FX rate, terms of trade volatility, stock market volatility and stock market index. Basically their model is based on structural model of defaults.

Ordinary Least Square regression model that is used structural models of credit risk that are based on Merton's model (1974). This theory suggests the determinants of credit spreads: Interest rate, equity prices and equity volatility. As we mentioned previous part, researchers developed this model adding new variables. Furthermore, some researchers have found that CDSs are good indicator of changes in credit risk quickly. For instance, Van (2004) studied that there is a relationship between credit default swap and volatility. Besides, Gapen (2005) develop structural model towards sovereign credit risk. Furthermore, Merton (1974) model should be considered to understand structural model. Basically, structural approach is based on corporate credit risk. The following years Gapen (2005) added sovereign credit risk to this model. He used volatility to determine sovereign. Our aim will be identified the determinant of CDS spreads. Thus, we have used structural model to determine CDS spreads. We will be shown that the sovereign risk is associated with higher CDS spreads. We will be proved that there is a correlation between equity indices and CDS spreads; volatility index and CDS spreads.

Empirical research is usually associated with establishing the trade-off between variables. For instance, how does one variable alter as another variable changes? Basically, variables represent a property of an event or phenomenon related to a particular subject. The variables take into consideration in empirical work may be dichotomized as dependent or independent variables. In this study, the dependent variable is CDS spreads. The explanatory variables are the S\&P 500 volatility index (VIX), MSCI World Financial Index (WF), S\&P 500 equity index (S\&P) and Interest rate swap (IRS). The explanatory variables in an experiment are the variables that are manipulated by the analyst; it is the impact of these variables that are being studied by the experimenter. The dependent variables are measure of the reaction to the manipulation. In the recent years other studies, Equity market index and the VIX index are correlated with CDS spreads. Besides, VIX index has an important impact on the CDS spread. ITraxx CDS spread is a good indicator of a common risk factor.

The main aim of the study will analyse sovereign credit default swap spreads of 4 countries: Portugal, Italy, Ireland and Spain during sovereign debt crisis. Besides, another purpose is to identify the determinant of credit default swap spreads. Regression analysis OLS (Ordinary Least Square) of spreads is conducted in SPSS 11.5 to explain which factors have an impact on the development of CDS spreads during 4 years period of time from 2008 to 2012. 


\subsection{Variables}

\subsubsection{MSCI World Finance Index}

MSCI World Financial index is extensively tracked global equity benchmark and helps as the basis over 500 exchanged traded funds in the world. Indices offer particular equity market coverage for over 70 countries which apply a consistent index construction. MSCI world financial index allows market participant global perspective and cross regional comparison across all market capitalization. A financial crisis might lead to growing default probability, as well as it causes higher credit default swaps. Dieckmann and Plank (2011) worked on the world financial system using principal component analysis; usually world financial indexes are strongly correlated with CDS spreads. Therefore, we used MSCI world financial index as an explanatory variables.

\subsubsection{S\&P 500 Volatility Index}

The index is an index of expected future price volatility implied via option prices. The VIX is supported by the Chicago Board Options Exchange (CBOE) in the U.S.A and is calculated utilizing S\&P 500 options market. The current symbol for this index is VIX. The VIX index shows implied volatility of the S\&P 500 stock for the next 30 days If the VIX rises, investors worried about future prices. The high value of index does not imply that the market will fall. In fact they show that investors anticipate that prices will move up or down substantially in the future. Basically, the method of calculation is quite simple; the volatility was received from a Black-Scholes model which is given a known market option price just for at the money options in 1990. In the middle of the 2000, the Chicago Board Options Exchange decided to introduce more complicated approach than Black-Scholes pricing model. Prices are used on the latest Wall Street mathematical gimmicks. According to Structural Model (1976), this model is related to option pricing. As a result, the volatility is important factor to determine credit spreads.

\subsubsection{Interest Swap Rate (ISR)}

According to the Merton's model (1974) alters in the risk free interest rate in general are generally related to credit spreads. Basically, an increase in the risk free rate of interest might decrease the credit spreads. A rising risk free rate of interest decreases the present value of future cash flows, for instance, price of put option decreases. Alexander (2010) also worked on Merton's (1974) model with using interest rate, equity price and equity volatility. The period covers daily data from 2004 to 2007 on the ITraxx Europe credit swap index. The coefficients on the equity return and equity volatility are significant. Implied volatility is also very significant variable to determine credit spread. Also Vorst and Houweling (2005) utilized the swap rate as a proxy of the risk free interest rate and find a stronger effect on the swap rate on the CDS market than that of the treasury rate. Therefore in our analysis, we utilized Euro interest rate swap as a proxy measure of the risk free rate.

\subsubsection{S\&P 500 Equity Index}

S\&P 500 Equity Index is a stock market index including the stocks of large US companies in various key industries. The index was officially established by standard and poor's in 1957. Moreover, index is designed to measure of the economy through alters in the aggregate market value of 500 stocks which show leading industries. S\&P 500 Equity Index shows over 75 per cent of the U.S. equity mark so it is taken in to consideration a benchmark for the U.S. market. Moreover, S\&P 500 Equity Index is weighted via market capitalization. S\&P 500 Equity Index is a good investment strategy that seems a beneficial long term total return by investing in a portfolio of expansive domestic companies elected to tract the U.S. equity market which is based on the stock market index. Futures, options, and mutual funds offer investment opportunities to trade S\&P 500 Equity Index. According to Longstaff (2004), a US market equity index is highly correlated with CDS spreads. Thus, we used S\&P 500 index as one of the independent variables. You can see analysis of model descriptive statistics below.

Table 1. Descriptive statistics

\begin{tabular}{lccccc}
\hline & $\mathrm{N}$ & Minimum & Maximum & Mean & Std. Deviation \\
\hline Germany & 1052 & 5,20 & 118,39 & 44,8862 & 25,82256 \\
Italy & 1052 & 24,50 & 586,70 & 180,6134 & 133,44665 \\
Spain & 1052 & 24,00 & 484,09 & 186,2302 & 124,70045 \\
Ireland & 1052 & 18,00 & 1249,30 & 358,9907 & 275,59657 \\
Portugal & 1052 & 21,60 & 1600,98 & 358,5174 & 397,39152 \\
\hline
\end{tabular}




\begin{tabular}{lccccc}
\hline VIX & 1052 & 14,26 & 80,86 & 27,0378 & 11,49820 \\
SP & 1052 & 676,53 & 1426,63 & 1152,5329 & 172,39734 \\
MSCI & 1052 & 11,88 & 40,02 & 30,2636 & 6,57266 \\
ISR & 1052 & 2,31 & 5,25 & 3,9222 &, 69052 \\
\hline
\end{tabular}

\section{Empirical Analysis}

\subsection{Spain}

Table 2. Spain regression statistics

\begin{tabular}{|c|c|c|c|c|c|}
\hline \multicolumn{6}{|c|}{ Regression Statistics } \\
\hline \multicolumn{3}{|l|}{ Multiple R } & \multicolumn{3}{|l|}{, 882} \\
\hline \multicolumn{3}{|l|}{ R Square } & \multicolumn{3}{|l|}{, 778} \\
\hline \multicolumn{3}{|c|}{ Adjusted R Square } & \multicolumn{3}{|l|}{, 777} \\
\hline \multicolumn{3}{|c|}{ Standard Error } & \multicolumn{3}{|l|}{29,824} \\
\hline \multicolumn{3}{|c|}{ Observations } & \multicolumn{3}{|l|}{1051} \\
\hline \multicolumn{6}{|l|}{ ANOVA } \\
\hline & $d f$ & SS & $M S$ & $F$ & Significance F \\
\hline Regression & 4 & $12,714,314,149$ & $3,178,578,537$ & 917,062 &, 000 \\
\hline Residual & 1047 & $3,628,948,342$ & \multicolumn{3}{|l|}{$3,466,044$} \\
\hline \multirow[t]{2}{*}{ Total } & 1051 & $16,343,262,490$ & & & \\
\hline & Coefficients & Standard Error & $t$ Stat & $P$-value & \\
\hline Constant & $-62,207$ & 27,122 & $-2,294$ &, 022 & \\
\hline VIX & 5,082 & ,296 & 17,173 &, 000 & \\
\hline $\mathrm{S} \& \mathrm{P}$ &, 103 &, 020 & 5,218 &, 000 & \\
\hline MSCI & 15,839 & ,669 & 23,681 &, 000 & \\
\hline IRS & $-124,261$ & 2,702 & $-45,983$ &, 000 & \\
\hline
\end{tabular}

Analysis of Spain R squared is really high at about 77 per cent. Statistically it means that independent variables are able to explain 77 per cent of the variation in CDS spreads during four years period of time. However, if we want to know more information about goodness of model fit, we had better look F test for goodness of fit through ANOVA test. The value of the significance $F$ statistic is small than $0,05(\mathrm{~F}<0,05)$ therefore we reject null hypostudy $\left(\mathrm{H}_{0}\right)$.

$$
\text { CDS Spreads }=-62.20+5.08 \mathrm{VIX}+0.10 S \& P+15.8 \mathrm{MSCI}-124.2 \mathrm{IRS}
$$

When we look equation, we can say there is a positive relationship among CDS spreads and VIX, S\&P and MSCI. In contrast there is a negative relationship between IRS and Spain CDS spreads. The coefficients on VIX, S\&P, MSCI and IRS are statistically significant, in other words VIX, S\&P, MSCI, and IRS are enough to explain CDS spreads in Spain. Because t values $(17.1>1.64$, 5.21 $>1.64,23.6>1.64$ and $45.9>1.64)$ and $p$ values $(0.00<0.05,0.00<0.05,0.00<0.05$ and $0.00<0.05)$ are statistically significant. 


\subsection{Italy}

Table 3. Italy regression statistics

\begin{tabular}{|c|c|c|c|c|c|}
\hline \multicolumn{6}{|c|}{ Regression Statistics } \\
\hline \multicolumn{3}{|l|}{ Multiple R } & \multicolumn{3}{|l|}{882} \\
\hline \multicolumn{3}{|l|}{ R Square } & \multicolumn{3}{|l|}{,779 } \\
\hline \multicolumn{3}{|c|}{ Adjusted R Square } & \multicolumn{3}{|l|}{,778 } \\
\hline \multicolumn{3}{|c|}{ Standard Error } & \multicolumn{3}{|l|}{31,876} \\
\hline \multicolumn{3}{|c|}{ Observations } & \multicolumn{3}{|l|}{1051} \\
\hline \multicolumn{6}{|l|}{ ANOVA } \\
\hline & $d f$ & SS & $M S$ & $F$ & Significance $F$ \\
\hline Regression & 4 & $14,570,774,533$ & $3,642,693,633$ & 920,023 &, 000 \\
\hline Residual & 1047 & $4,145,442,148$ & \multicolumn{3}{|l|}{$3,959,353$} \\
\hline \multirow[t]{2}{*}{ Total } & 1051 & $18,716,216,680$ & & & \\
\hline & Coefficients & Standard Error & $t$ Stat & P-value & \\
\hline Constant & 71,591 & 28,988 & 2,470 &, 014 & \\
\hline VIX & 5,256 &, 316 & 16,618 &, 000 & \\
\hline $\mathrm{S} \& \mathrm{P}$ &, 230 &, 021 & 10,848 &, 000 & \\
\hline MSCI & 10,011 &, 715 & 14,005 &, 000 & \\
\hline IRS & $-153,140$ & 2,888 & $-53,022$ &, 000 & \\
\hline
\end{tabular}

Analysis of Italy, R-squared of this analysis is high at almost 80 per cent. Therefore, the independent variables are able to explain almost 80 per cent of the variation in CDS during 4 years period of time. These results give a good indication that the model fits and data is well. When we look $\mathrm{F}$ statistics $(\mathrm{F}<0,05)$ we can reject null hypostudy, accept our hypostudy. For Italy global equity indices, volatility, and interest rate swap triggers changes CDS spreads. In other words, independent variables which are used in this model are good indicator to determine Italian CDS spreads.

$$
\text { CDS Spreads }=75,591+5,25 \mathrm{VIX}+0,23 \mathrm{~S} \& P+10,01 \mathrm{MSCI}-153 \mathrm{IRS}
$$

The equation shows that there is a positive relationship between VIX index and CDS spreads, similarly there is a positive relationship between S\&P 500 equity index and CDS spreads, as well as there is a positive relationship between MSCI world finance index and CDS spreads in Italy. Nevertheless, there is a negative relationship between European interest rate swap and CDS spreads. We can say that there is a strong negative relationship between CDS Italy spread and European interest rate swap.

Furthermore the table demonstrates that the coefficient on VIX index, S\&P 500 index, and MSCI world finance index are statistically significant, in other words VIX index, S\&P 500 index and MSCI world finance index are enough to explain in Italian CDS spreads. Because, $t$ values are statistically significant.

\subsection{Ireland}

Table 4. Ireland regression statistics

\begin{tabular}{ll}
\hline Regression Statistics & \\
\hline Multiple R &, 808 \\
R Square &, 653 \\
Adjusted R Square &, 652 \\
Standard Error & 84,214 \\
\hline
\end{tabular}




\begin{tabular}{llllll}
\hline Observations & \multicolumn{5}{c}{1051} \\
\hline ANOVA & & & & & \\
& $d f$ & $S S$ & $M S$ & $F$ & Significance $F$ \\
\hline Regression & 4 & $52,149,522,382$ & $13,037,380,595$ & 493,184 &, 000 \\
Residual & 1047 & $276,777,571,609$ & $26,435,121$ & & \\
Total & 1051 & $79,827,093,991$ & & & \\
\hline & Coefficients & Standard Error & t Stat & P-value & \\
\hline Constant & $-402,164$ & 74,904 & $-5,369$ &, 000 & \\
VIX & 13,195 &, 817 & 16,146 &, 000 & \\
S\&P &, 139 &, 055 & 2,547 &, 011 & \\
MSCI & 38,240 & 1,847 & 20,703 &, 000 & \\
IRS & $-232,886$ & 7,463 & $-31,206$ &, 000 & \\
\hline
\end{tabular}

$\mathrm{R}$-squared is a measure of proportion of the variation on the dependent variable accounted by the explanatory variables. Furthermore $\mathrm{R}$ squared is greater than $\mathrm{R}$ squared, because degrees of freedom are added $\mathrm{R}$ squared. If we want to know more information about goodness of model fit, we should look the F test for goodness of fit. The value of the significance $F$ statistic is small than $0,05(\mathrm{~F}<0,05)$ therefore we reject null hypostudy $\left(\mathrm{H}_{0}\right)$.

$$
C D S \text { spreads }=-402.16+13.1 \text { VIX }+0.13 S \& P 500+38.2 M S C I-232 I R S
$$

Equation shows that there is a positive relationship between Ireland CDS spreads and VIX; there is a positive relationship between Ireland CDS spreads and S\&P500 as well. There is a positive relationship between Ireland CDS spreads and MSCI but there is a negative relationship similar other countries, between Ireland CDS spreads and Euro interest swap rate.

The coefficient on VIX, S\&P, MSCI and Euro interest swap rate are statistically significant. Put another way, VIX, S\&P, MSCI and Euro interest swap rate are able to explain Ireland CDS spreads. On the grounds that $t$ values and $p$ values are statistically significant.

\subsection{Portugal}

Table 5. Portugal regression statistics

\begin{tabular}{|c|c|c|c|c|c|}
\hline \multicolumn{6}{|c|}{ Regression Statistics } \\
\hline \multicolumn{3}{|l|}{ Multiple R } & \multicolumn{3}{|l|}{,902 } \\
\hline \multicolumn{3}{|l|}{ R Square } & \multicolumn{3}{|l|}{, 814} \\
\hline \multicolumn{3}{|c|}{ Adjusted R Square } & \multicolumn{3}{|l|}{, 813} \\
\hline \multicolumn{3}{|c|}{ Standard Error } & \multicolumn{3}{|l|}{89,138} \\
\hline \multicolumn{3}{|c|}{ Observations } & \multicolumn{3}{|l|}{1051} \\
\hline \multicolumn{6}{|l|}{ ANOVA } \\
\hline & $d f$ & $S S$ & $M S$ & $F$ & Significance $F$ \\
\hline Regression & 4 & $135,027,371,450$ & $33,756,842,862$ & 1142079 &, 000 \\
\hline Residual & 1047 & $30,946,568,648$ & \multicolumn{3}{|l|}{$29,557,372$} \\
\hline \multirow[t]{2}{*}{ Total } & 1051 & $165,973,940,098$ & & & \\
\hline & Coefficients & Standard Error & $t$ Stat & $P$-value & \\
\hline Constant & $-486,933$ & 79,204 & $-6,148$ &, 000 & \\
\hline VIX & 12,385 &, 864 & 14,332 &, 000 & \\
\hline S\&P & 1,195 &, 058 & 20,661 &, 011 & \\
\hline
\end{tabular}




\begin{tabular}{lllll}
\hline MSCI & 25,334 & 1,953 & 12,971 &, 000 \\
IRS & $-416,328$ & 7,981 & $-52,758$ &, 000 \\
\hline
\end{tabular}

$\mathrm{R}$ square of this analysis is high very at 81 per cent. Therefore the independent variables are able to explain 81.4 per cent of the variation in CDS spreads during 4 years period of time. For these reasons the model fits and data is well. The value of the significance $F$ statistic is small than $0,05(\mathrm{~F}<0,05)$ therefore we reject null hypostudy $\left(\mathrm{H}_{0}\right)$.

$$
\text { CDS Spreads }=-486+12,3 \mathrm{VIX}+1,19 \mathrm{~S} \& P+25.3 \mathrm{MSCI}-416,3 \mathrm{IRS}
$$

The equation demonstrates that there is a positive relationship between VIX and CDS spreads, as well as there is a positive relationship between S\&P 500 and CDS spreads. There is also positive relationship between MSCI and CDS spreads. In contrast there is a negative relationship between interest rate and CDS spreads.

The coefficient on the VIX, S\&P and MSCI are statistically significant, in other words VIX, S\&P, and MSCI are enough to explain CDS spreads. Because table shows that $\mathrm{t}$ values $(14.3>1.64,20.6>1.64$ and $27.8>1.64)$ are statistically significant, and $p$ values $(0.00<0.05,0.00<0.05$ and $0.00<0.05)$ are also statistically significant.

\subsection{Germany}

Table 6. Germany regression statistics

\begin{tabular}{|c|c|c|c|c|c|}
\hline \multicolumn{6}{|c|}{ Regression Statistics } \\
\hline \multicolumn{2}{|l|}{ Multiple R } & & ,854 & & \\
\hline \multicolumn{2}{|l|}{ R Square } & \multicolumn{4}{|c|}{, 729} \\
\hline \multicolumn{2}{|c|}{ Adjusted R Square } & \multicolumn{4}{|c|}{, 728} \\
\hline \multicolumn{2}{|c|}{ Standard Error } & \multicolumn{4}{|c|}{6,200} \\
\hline \multicolumn{2}{|c|}{ Observations } & \multicolumn{4}{|c|}{1051} \\
\hline \multicolumn{6}{|l|}{ ANOVA } \\
\hline & $d f$ & $S S$ & $M S$ & $F$ & Significance F \\
\hline Regression & 4 & $511,182,098$ & $127,795,524$ & 705,596 & ,000 \\
\hline Residual & 1047 & $189,629,648$ & 181,117 & & \\
\hline \multirow[t]{2}{*}{ Total } & 1051 & $700,811,746$ & & & \\
\hline & Coefficients & Standard Error & $t$ Stat & $P$-value & \\
\hline Constant & 37,493 & 6,200 & 6,047 & ,000 & \\
\hline VIX & 1,215 &, 068 & 17,969 &, 000 & \\
\hline $\mathrm{S} \& \mathrm{P}$ &, 019 &, 005 & 4,156 &, 011 & \\
\hline MSCI & 2,189 &, 153 & 14,317 &, 000 & \\
\hline IRS & $-28,912$ & ,618 & $-46,803$ &, 000 & \\
\hline
\end{tabular}

Our benchmark country which is German of R squared value is really high at 72 per cent, in other words the independent variables are able to explain 72 per cent of the variation in CDS spreads. F value exceeds the critical $\mathrm{F}$ value. The value of the significance $\mathrm{F}$ statistic is small than $0,05(\mathrm{~F}<0,05)$ therefore we reject null hypostudy $\left(\mathrm{H}_{0}\right)$. Thus, the model fits and the data is well indeed.

$$
\text { CDS Spreads }=37.4+1.21 \text { VIX+0.01S\&P+2.18MSCI-28.9IRS }
$$

This equation shows that there is a positive relationship between VIX and German CDS spreads, there is also positive relationship between S\&P and German CDS spreads, as well as there is a positive relationship between MSCI and Germany CDS spreads. In contrast, there is a negative relationship between European interest rate and German CDS spreads. Table shows that the coefficient on VIX, S\&P, MSCI and European interest rate are statistically significant which means that VIX, S\&P, MSCI and European interest rate are enough to explain 
German CDS spreads. On the grounds that $\mathrm{t}$ values $(17.9>1.64,4.15>1.64,14.3>1.64$ and $46.8>1.64)$ and $\mathrm{p}$ values $(0.00<0.05,0.00<0.05,0.00<0.05$ and $0.00<0.05)$ for independent variables are statistically significant.

\section{Conclusion}

As it is known that 2007-2008 financial crises dominated the entire world. Although the source crisis emergence America, it spread all the world countries as soon. Especially European countries have damaged this crisis dramatically. This countries have challenged and fighting volatility currently. Their indebtness increase and most of them financial sector has gone bankrupt. Also its known that financial sector managing all sectors nowadays.

As we know that core countries more developed than periphery countries. Basically, periphery countries have unstable government and fiscal problem. European periphery countries have been struggling in heavy borrowing problem during sovereign debt crisis. This crisis has occurred since 2007 and borrowing rate became doubled in Ireland Greece, Italy, Portugal, and Spain. CDS spreads for these countries dramatically decreased because of their debts. These countries have paid attention in the world since occurring sovereign debt crisis. Therefore, we decided to use Italy, Portugal, Spain, and Ireland's CDS spreads to analyze sovereign debt crisis.

This study searched sovereign CDS spreads in the euro area periphery countries: Portugal, Ireland, Spain and Italy, during 4 years period of time from 2008 to 2012. Germany is considered as a benchmark country. This study has also focused on the debt levels and the subversive countries such as Ireland and Portugal.

Our aim was to explain the theoretical determinants relied on the structural model and has focused on global factors. OLS regression was used to determine the relationship between equity indices and CDS spreads; volatility index and CDS spreads. ITraxx index is the most important index for global factor. Thus CDS data was obtained iTraxx through Thomson Reuters. S\&P 500 volatility index has significant factor for Ireland, Portugal, Spain and Italy to determine sovereign CDS spreads during sovereign debt crisis period.

As a result of this study, there is a positive relationship VIX index and CDS spreads. Similarly there is a positive relationship between S\&P 500 equity index and CDS spreads as well as there is a positive relationship between MSCI world finance index and CDS spreads. Nevertheless there is a negative relationship between European interest rate swap and CDS spreads.

Furthermore it has been investigated theoretical determinant of credit risk and CDS spreads. These determinants are volatility and equity indexes, namely MSCI World Financial Index, S\&P 500 Volatility Index, FTSE World Europe Index and S\&P 500 Equity Index. We found that there is a strong correlation between these determinants and iTraxx sovereign CDS spreads. Besides these explanatory variables are statistically significant in the euro are periphery Countries: Portugal, Italy, Spain and Ireland. In OLS regression analysis for Germany, which is, used benchmark country, these explanatory variables results are statistically significant except S\&P 500 Equity Index.

The effects of risk premiums on CDS spreads are associated with macroeconomic and financial market developments. Second part of this study, macroeconomic and financial markets developments has been investigated. Our result show that sovereign spreads has increased dramatically in Portugal, Italy, Ireland and Italy. This circumstance changed on investor's appetites for credit exposure at a global level rather than these specific sovereign economies (Pan \& Singleton, 2008). This development has damaged macroeconomic factors, such as GDP, growth rate and debt to GDP ratio.

\section{References}

Akdogu, S. (2012). CDS, bond spread and sovereign debt crisis in peripherals EU (pp. 126-133). Szeged: University of Szeged.

Alexander, C. (2010). Quantitative methods in finance (3rd ed.). London: John Wiley \& Sons, Ltd.

Alexander, C., \& Kaeck, A. (2007). Regime dependent determinants of credit default swap spreads. Journal of Banking and Finance, 32(6), 1008-1021. http://dx.doi.org/10.1016/j.jbankfin.2007.08.002

Alexopolou, L., Bunda, I., \& Ferrando, A. (2009). Determinant of government bond spreads in new EU countries (1st ed.). New York: European Central Bank.

Alper, E., Forni, L., \& Gerard, M. (2012). Pricing of sovereign credit risk (1st ed.). Washington: International Monetary Fund.

Andrew, A., \& Longstaff, F. A. (2011). Systemic sovereign credit risk: Lessons from the US and Europe. SSRN Working Paper.

Asrtid, L. A. (2004). Determinants of Euro term structure of credit spreads. European Central Bank, Working 
paper Series, No. 397.

Asteriou, D., \& Hall, S. (2009). Applied econometrics (2nd ed.). Chine: Palgrave Macmillan.

Astrid, V. L. (2004). Determinants of Euro term structure of credit spreads. Working Paper Series 0397, European Central Bank.

Atrissi, N., \& Mezher, F. (2010). Sovereign debt crisis and credit default swaps: The case of greece and other PIIGS. Maître de Conférences à la FGM, Written July 2010, Université Saint-Joseph, Beyrout.

Augustin, P. (2012). Sovereign credit default swap premia. Stockholm School of Economics, Finance Department.

Badaoui, S., Cathcart, L., \& El-Jahel, L. (2012). Do sovereign credit default swaps represent a clean measureof sovereign default risk? A Factor Model Approach. London, Imperial College Business School.

Barrios, S. P., Iversen, M., \& Lewandowska, R. S. (2009). Determinants of Intra-Euro area government bond spreads during the financial crisis. European Economy, Economic Papers 388, November.

Bilal, M., \& Singh, M. (2012). CDS spreads in European periphery (1st ed.). Washington: International Monetary Fund.

Black, F. (1976). Studies of stock price volatility changes. Proceedings of the 1976 Meetings of the American Statistical Association, 177-181.

Black, F., \& Scholes, M. (1973). The pricing of options and corporate liabilities. Journal of Political Economy, 81, 637-654. http://dx.doi.org/10.1086/260062

Blanco, B., Brennan, S., \& Marsh, W. I. (2008). An empirical analysis of the dynamic relation between investment-grade bonds and credit default swaps. Journal of Finance, IX(5), 2-3.

Bolton, P., \& Olivier, J. (2011). Sovereign default risk and bank fragility in financially integrated economies. NBER Working Paper 1689.

Bomfim, A. (2005). Understanding credit derivatives and related instruments (1st ed.). London: Elsevier Academic Press.

Breitenfellner, B., \& Wagner, N. (2012). Explaining aggregate credit default swap spreads. 22, 18-19.

Calice, G., Chen, J., \& Willams, J. (2011). Liquidity spillovers in sovereign bond and CDS markets. London.

Contessi, S. (2012). An application of conventional sovereign debt sustainability analysis to the current debt crises. St Louis, Federal Reserve Bank of St. Louis.

Criado, S. (2012). Report on sovereign CDS: Magdalena, Market.

Delatte, A. L., Gex, M., \& Villavicencio, A. L. (2010). Has the market amplified the European sovereign crisis? A non-linear approach.

Dieckmann, S., \& Plank, T. (2011). Default risk of advanced economies: An empirical analysis of credit default swaps during the financial crisis. Review of Finance.

Duffee, G. R. (1996). Treasury yields and corporate bond yield spreads: An empirical analysis. Finance and Economics Discussion Series, 20.

Duffee, G. R. (1999). Estimating the price of default risk. The Review of Financial Studies, 1, 197-226. http://dx.doi.org/10.1093/rfs/12.1.197

Duffie, D. (1996). Dynamic asset pricing theory (2nd ed). Princeton, NJ: Princeton University Press.

Duffie, D., \& Kenneth, J., S. (2003). Credit risk. Princeton, NJ: Princeton University Press.

Duffied, J. M. A., \& Yonc, J. (1995). Black's console rate conjecture. Ann. Appl. Probab., 5, 356-382. http://dx.doi.org/10.1214/aoap/1177004768

Ericson, J., Jacobs, K., \& Ovieado, T. (2005). The determinants of credit default swap premia. Journal of Financial and Quantitative Analysis, 44(2), 109-132.

Flannery, M. J. (2009). The subprime crisis: Lessons about market discipline. World Scientific Studies in International Economics, 10, 281-305.

Fontana, A., \& Scheicher, M. (2010). An analysis of Euro area sovereign CDS and their relation with government bonds. European Central Bank. 
Galtung, J. (2006). A structural theory of imperialism. Journal of Peace Research, 8(2), 2-117.

Gapen, M. T., Gray, D. F., Lim, C. H., \& Xiao, Y. B. (2005). Measuring and analyzing sovereign risk with contingent claims. IMF Working Paper, 155, August.

Gerlach, S., Schulz, A., \& Wolf, B. G. (2010). Banking and sovereign risk in the Euro Area. Frankfurt: Deutsche Bank.

Granger, J. W. C. (2007). Investigating causal relations by econometric models and cross-spectral methods. JSTOR, 37(3), 424-438.

Holland, D., Kirby, S., \& Orazgani, S. (2011). Modelling the sovereign debt crisis in Europe. National Institute Economic Review, 217(37), 5-8.

Hull, J. C., \& White, A. (2000). Valuing credit default swaps: No counterparty default risk. SSRN eLibrary.

Hull, J., Predescu, M., \& White, A. (2004). The relationship between credit default swap spreads, bond yields, and credit rating announcement (2nd ed.). Toronto: Rotman Business School.

IMF. (2006). Global financial stability report. Working paper, Capital Markets Division, September. International Monetary Fund.

J. P. Morgan Company. (2010). Investment analytics and consulting newsletter archive.

J. P. Morgan Company. (2012). Investment analytics and consulting newsletter archive.

Jarrow, A. R., \& Turnbull, M. S. (1995). Pricing derivatives on financial securities subject to credit risk. The Journal of Finance, 1(1).

Kiff, J., Elliot, J., Kazarian, E., Scarlata, J., \& Spaceman, C. (2009). Credit derivative systematic risk and policy options (1st ed.). Washington: International Monetary Fund.

Klieber, S. D. (2012). Credit default swaps weapon of mass destruction or reliable indicator. England: Oxford.

Longstaf, F. A., Pan, J., Pedersen, L. H., \& Singleton, K. J. (2010). How sovereign is sovereign credit risk? American Economic Journal: Macroeconomics.

Longstaff, F. A. (2004). The flight to liquidity premium in U.S. treasury bond prices. Journal of Business, 77, 511-526. http://dx.doi.org/10.1086/386528

Longstaff, F. A., Mithal, S., \& Neis, E. (2005). Corporate yield spreads: Default risk or liquidity? New evidence from the credit default swap market. Journal of Finance, 60(5), 2213-2253. http://dx.doi.org/10.1111/j.1540-6261.2005.00797.x

Masters, B., Herring, J., \& Ikeda, M. (2005). The J.P Morgan guide to credit derivatives. New York: JP Morgan.

Merton, C. R. (1974). On the pricing of corporate debt: The risk structural of interest rates. Journal of Finance, 29, 449-470.

Merton, R. C. (1973). Theory of rational option pricing. Bell Journal of Economics and Management, 4, 141182. http://dx.doi.org/10.2307/3003143

Merton, R. C. (1976). Option pricing when underlying stock returns are discontinuous. Journal of Financial Economics, 3, 125-144. http://dx.doi.org/10.1016/0304-405X(76)90022-2

Mody, A., \& Sandri, D. (2011). The Eurozone crisis: How banks and sovereigns came to be joined at the Hip. Washington: International Monetary Fund.

Mora, N. (2006). Sovereign credit ratings: Guilty beyond reasonable doubt? Journal of Banking and Finance, 30.

O’Kane, D., \& Turnbull, S. (2003). Valuation of credit swap. Fixed Quantitative Credit Research, 3-11.

Ozveren, N. A. (2009). Credit default swap: An assessment and pricing issues. Ankara: Middle East Technical University.

Pan, J. (2002). The jump-risk premia implicit in options: Evidence from an integrated time-series study. Journal of Financial Economics, 63, 3-50. http://dx.doi.org/10.1016/S0304-405X(01)00088-5

Pan, J., \& Singleton, J. K. (2008). Default recovery implicit in the term structure of sovereign CDS spreads. The Journal of Finance, LXIII(5).

Plank, J. T. (2010). Essay in sovereign credit risk. Pennsylvania, University of Pennsylvania Scholarly Commons. 
$\mathrm{Pu}, \mathrm{X}$., \& Zhang, J. (2012). Sovereign CDS spreads, volatility, and liquidity: Evidence from 2010 german short sale ban. The Financial Review, 47, 171-197. http://dx.doi.org/10.1111/j.1540-6288.2011.00325.x

Puig, M. G., \& Rivero, S. S. (2011). Causality and contagion in peripheral EMU public debt markets; A dynamic approach. Research Institute of Applied Economics Working Paper 2011/16.

Reinhart, C., \& Rogoff, K. (2011). From financial crisis to debt crisis. American Economic Review, 101, 16761706.

Reinhart, C., \& Rogoff, K. (2011). This time is different eight centuries of financial folly (1st ed.). New York: Princeton. http://dx.doi.org/10.1257/aer.101.5.1676

Santis, A. R. (2010). The Euro area sovereign debt' crisis safe haven, credit rating agencies and the spread of the fever from Greece, Ireland \& Portugal (1st ed.). Germany: European Central Bank.

Sorensen, K., \& Winckelmann, A. D. (2011). Analysis of European sovereign CDS spreads before and after the financial crisis (1st ed.). Denmark: Aarhus School of Business.

Tang, D., \& Yan, H. (2007). Liquidity and credit default swap spreads. Chicago Meetings Papers, AFA.

Vorst, T., \& Houweling, P. (2005). Pricing default swaps: Empirical evidence. Elsevier, 24, 1200-1225.

Watsham, T. (1998). Futures and options in risk management (2nd ed.). London: Thomson Business Press.

White, A., \& Hull, J. (2003). Valuing credit default swaps (1st ed.). Toronto: Rootman School of Management.

\section{Copyrights}

Copyright for this article is retained by the author(s), with first publication rights granted to the journal.

This is an open-access article distributed under the terms and conditions of the Creative Commons Attribution license (http://creativecommons.org/licenses/by/3.0/). 